\title{
STRATEGI PENINGKATAN KETERAMPILAN BAHASA INGGRIS PELAKU WISATA DI DESA WISATA TISTA, KERAMBITAN, TABANAN
}

\author{
Luh Sri Damayanti \\ Email: sri.damayanti@pib.ac.id \\ POLITEKNIK INTERNASIONAL BALI
}

\begin{abstract}
English communication is a problem faced by the human resources involved in the tourism activities in Desa Wisata Tista, Kerambitan Subdistrict, Tabanan Regency, Bali. However, there had been no research that identified English problems. Then, this research was done to (1) identify the problem faced by the human resources involved in tourism activities in Desa Wisata Tista, Kerambitan Subdistrict, Tabanan Regency, Bali and (2) finding out the proper and suitable English learning strategies to improve the English mastery of the human resources involved in the tourism activities in Desa Wisata Tista, Kerambitan Subdistrict, Tabanan Regency, Bali. The data used in this research were gained through interviews, observation, and literature studies. The data were analyzed qualitatively. The results of the analysis reveal that (1) the numbers of the human resources who can speak English is limited, (2) the lack of speaking skills using English, (3) the lack of English vocabulary they have, and (4) low level of self-confidence to communicate in English. These problems can be overcome by implementing several strategies, namely (1) memory strategy, (2) cognitive strategy, (3) affective strategy and (4) social strategy. Based on the identification, the managers can conduct English course for the community.
\end{abstract}

Keywords: English Communication, English Learning Strategies, English Communication Problems, English for Tourism Workers

\begin{abstract}
ABSTRAK
Komunikasi dengan menggunakan Bahasa Inggris merupakan suatu permasalahan yang dihadapi oleh para pelaku wisata di Desa Wisata Tista, Kecamatan Kerambitan, Kabupaten Tabanan, Bali. Namun belum ada penelitian yang mengakaji lebih dalam tentang permasalahan komunikasi Bahasa Inggris yang dihadapi sehingga penelitian ini dilakukan. Penelitian ini bertujuan untuk (1) mengidentifikasi permasalahan komunikasi Bahasa Inggris yang dihadapi oleh pelaku wisata di Desa Wisata Tista, dan (2) menemukan strategi yang dapat
\end{abstract}


dilakukan untuk meningkatkan kemampuan Bahasa Inggris pelaku wisata di Desa Wisata Tista. Data yang digunakan dalam penelitian ini diperoleh dari hasil wawancara, observasi, dan studi literatur. Data dianalisis secara kualitatif. Hasil analisis menunjukkan bahwa permsalahan yang dihadapi berkaitan dengan kemampuan berbahasa Inggris adalah (1) jumlah pelaku wisata yang mampu berbahasa Inggris sangat terbatas, (2) kurangnya keterampilan berbicara dengan menggunakan Bahasa Inggris, (3) kurangnya kosa kata Bahasa Inggris yang dimiliki, serta (4) rendahnya tingkat kepercayaan diri yang dimiliki untuk berkomunikasi dalam Bahasa Inggris. Permaslahan-permasalahan tersebut dapat diatasi dengan menerapkan beberapa strategi, yaitu (1) memory strategy, (2) cognitive strategy, (3) affective strategy dan (4) social strategy. Diidentifikasinya permasalahan-permasalahan tersebut, pihak pengelola dapat membangun sebuah komunitas belajar Bahasa Inggris untuk membantu seluruh pelaku wisata di Desa Wisata Tista meningkatkan kemampuan Bahasa Inggris.

Kata Kunci: Keterampilan Bahasa Inggris, Strategi Peningkatan, Pelaku Wisata

\section{Pendahuluan}

Desa wisata menjadi jalan tengah bagi dunia pariwisata dan taraf hidup masyarakat. Desa wisata memberikan pengalaman baru bagi wisatawan untuk merasakan langsung kehidupan masyarakat lokal. Ini dapat membangkitkan rasa senang dan puas dalam diri wisatawan. Desa wisata juga menjanjikan peningkatan perekonomian masyarakat sekitar. Ketika pariwisata berkembang maka sumber daya manusia dari daerah tersebut akan terserap sehingga perekonomian masyarakat turut serta meningkat. Desa Tista merupakan salah satu desa di Kabupaten Tabanan, Bali yang telah mengembangkan desanya menjadi sebuah desa wisata. Desa wisata ini memiliki banyak potensi wisata, seperti potensi wisata religi, potensi wisata alam, potensi wisata kuliner, dan potensi wisata seni dan budaya. Untuk wisata religi, Desa Wisata Tista menawarkan wisata ke 2 pura dan satu ke tempat yang disakralkan oleh masyarakat Desa Tista. Ini akan memberikan pengalaman wisata baru bagi para wisatawan untuk mengetahui dan mengalami langsung bagaimana kehidupan 
spiritual masyarakat Desa Tista. Potensi area persawahan yang luas dimanfaatkan oleh masyarakat sebagai tempat trekking bagi wisatawan. Wisatawan akan diajak untuk berkeliling di areal persawahan sehingga mengenal kehidupan petani di Desa Tista. Selain menyajikan wisata religi dan alam, Desa Wisata Tista juga memiliki keunikan dalam bidang kulinernya, yaitu olahan ubi ungu, mengkudu, olahan ikan lele, nasi bejek, serta sereh. Tidak hanya kaya potensi dalam dunia kuliner, alam, dan religi, Desa Tista juga memiliki potensi besar dalam seni dan budaya. Tari Andir merupakan kesenian khas Desa Wisata Tista yang hanya ditarikan pada hari- hari tertentu. Ini menjadi daya tarik besar bagi wisatawan untuk datang dan berkunjung serta untuk mengetahui tarian khas Desa Tista.

Sebagai salah satu desa wisata di Bali, dan salah satu industri pariwisata terbesar di dunia, Desa Tista telah dikelola dengan baik oleh masyarakat. Ini dapat dilihat dari tersedianya akses informasi berupa website desa yang nantinya memudahkan para wisatawan untuk menemukan informasi tentang desa ini. Pada tahun 2017 Sulistyawati \& Suarka dari Universitas Udayana menemukan bahwa dalam pengelolaannya, Desa Wisata Tista masih menemui hambatan dan kendala-kendala. Salah satu kendala yang dihadapi oleh masyarakat dalam mengelola desa wisata ini adalah bahasa. Keterbatasan dalam berbahasa menghambat para pelaku wisata dalam melakukan komunikasi dengan wisatawan, yang lebih banyak adalah wisatawan mancanegara.

Keterampilan berkomunikasi atau berbahasa asing menjadi isu yang penting dalam pengelolaan sebuah pariwisata. Seperti yang dikatakan oleh Karaman, Sayin \& Dinc (2015) bahwa komunikasi merupakan kunci yang esensial dalam industri pariwisata, khususnya dalam industri akomodasi serta pelayanan. Tesone \& Ricci (2015) juga menemukan hal yang sama bahwa komunikasi menjadi keterampilan yang diharapkan dimiliki oleh setiap pekerja di industri pariwisata. 
Kemampuan berkomunikasi dalam industri pariwisata merupakan hal wajib yang dimiliki oleh setiap praktisi pariwisata, terlebih keterampilan berbahasa Inggris. Adanya kesenjangan antara kemampuan yang seharusnya dimiliki oleh pengelola sebuah desa wisata dengan hambatan atau kendala berbahasa Inggris yang dihadapi dalam pengelolaan Desa Wisata Tista menjadi alasan mengapa penelitian ini dilakukan.

Merujuk pada permasalahan kendala berbahasa Inggris yang dihadapi oleh pelaku wisata di Desa Wisata Tista dalam mengelola desanya, maka terdapat 2 rumusan masalah yang akan menjadi fokus dalam penelitian ini. Rumusan masalah (1) bagaimanakah tantangan dan kesulitan dalam penggunaan Bahasa Inggris yang dihadapi oleh masyarakat Desa Wisata Tista, Kecamatan Kerambitan, Tabanan? Dan (2) Bagaimanakah strategi yang tepat untuk meningkatkan kemampuan Bahasa Inggris pelaku wisata di Desa Wisata Tista, Kecamatan Kerambitan, Tabanan?

Penelitian berkaitan dengan permasalahan dalam menggunakan Bahasa Inggris oleh pelaku pariwisata telah dilakukan oleh beberapa peneliti terdahulu. Salah satunya adalah Prachanant (2013) yang melakukan sebuah investigasi mengenai kebutuhan, fungsi, dan kendala berbahasa Inggris yang dihadapi oleh pelaku pariwisata di Thailand. Penelitian ini melibatkan 40 orang yang bekerja di lima perusahaan penyedia jasa tour bertaraf internasional di Thailand. Kelima perusahaan tersebut terletak di Bangkok, Chiangmai, Phuket, Samui, dan Pattaya. Empat puluh partisipan dalam penelitian ini terdiri dari 22 pria dan 18 perempuan yang telah bekerja selama $4-20$ tahun dalam industri pariwisata. Dalam mengumpulkan data yang diperlukan, peneliti menggunakan kuisioner atau angket yang terdiri dari tiga bagian, yaitu sebuah angket dengan menggunakan checklist, sebuah angket dengan menggunakan skala Likert, dan sebuah angket isian (open ended 
questionnaires). Data yang telah dikumpulan dianalisis secara kualitatif dan kuantitatif.

Hasil analisis menemukan empat kendala atau permasalahan yang dihadapi, yaitu (1) ketidakmampuan untuk memahami akses wisatawan asing, (2) wisatawan asing berbicara terlalu cepat sehingga kesulitan dalam memahami maksud pembicaraan, (3) ketidakmampuan untuk mengetahui arti dari kata-kata dalam Bahasa Inggris, dan (4) sedikitnya kesempatan untuk mendengarkan percakapan berbahasa Inggris. Selain menganalisis permasalahan dalam aspek mendengarkan (listening), peneliti juga menganalisis permasalahan dalam ranah berbicara (speaking). Permasalahan dalam ranah berbicara (speaking) antara lain (1) penggunaan kosa kata dan ekspresi yang tepat dalam berbicara, (2) kurangnya pemahaman dan penguasaan tata Bahasa Inggris, (3) kurangnya kepercayaan diri dalam berbicara menggunakan Bahasa Inggris, dan (4) ketidakmampuan untuk melafalkan kosa kata Bahasa Inggris dengan baik dan benar. Partisipan juga menemui kendala dalam hal membaca (reading), yaitu (1) tidak memiliki perbendaharaan kata yang memadai, (2) ketidakmampuan untuk memahami arti dan makna dari kosa kata Bahasa Inggris, (3) membaca teks yang terlalu panjang, serta (4) membaca teks yang tidak familiar.

Dalam ranah menulis (writing), terdapat empat permasalahan, yaitu (1) kurangnya penguasaan tata Bahasa Inggris, (2) ketidaktahuan bagaimana menulis, (3) tidak memiliki perbendaharaan kosa kata Bahasa Inggris yang memadai, dan (4) sedikitnya kesempatan untuk menulis. Penelitian oleh Prachanant (2013) ini menjadi referensi untuk penelitian yang diajukan ini mengingat terdapat kesamaan dalam hal atau objek yang diamati dalam penelitian, yaitu analisis terhadap fungsi Bahasa Inggris dalam industri pariwisata, kebutuhan Bahasa Inggris oleh pelaku pariwisata, dan kendala yang dihadapi dalam penggunaan Bahasa Inggris. 


\section{Konsep dan Teori}

Bagian ini akan dibagi menjadi dua sub-bab agar memudahkan pembaca dalam memahami isi dari artikel ini.

\subsection{Konsep}

Terdapat tiga konsep penting dalam penelitian ini, yaitu strategi, keterampilan Bahasa Inggris, serta pelaku wisata. Husain (2015) menyebutkan bahwa kemampuan berbahasa Inggris dapat dibagi menjadi dua yaitu, kemampuan menerima (receptive skill) dan kemampuan memproduksi (productive skill). Kemampuan menerima terdiri dari dua kemampuan, yaitu kemampuan mendengarkan dan kemampuan membaca. Sedangkan kemampuan memproduksi melingkupi kemampuan berbicara dan menulis. Keterampilan berbicara dan mendengarkan (listening \& speaking) merupakan berhubungan erat satu sama lain dan sangat diperlukan dalam kehidupan sehari-hari (Sadiku, 2015). Integrasi kedua keterampilan berbahasa Inggris ini membentuk dan membangun sebuah komunikasi yang efektif. Sedangkan keterampilan membaca dan menulis memiliki peran yang penting dalam menciptakan komunikasi tertulis yang efektif dan kedua keterampilan ini juga berkaitan satu sama lainnya (Sadiku, 2015). Kemampuan-kemampuan tersebut merupakan kemampuan berbahasa dasar yang harus dimiliki oleh pelaku wisata di suatu daerah wisata mengingat sehingga mampu meningkatkan pelayanan terhadap wisatawan, khususnya wisatawan asing yang berkunjung.

Murcia (2001) dikutip dari Noviyenty (2018) mengungkapkan bahwa strategi belajar merupakan kegiatan, langkah, dan teknik yang spesifik untuk mengatasi kesulitan berbahasa sehingga dapat meningkatkan proses pembelajaran. Cohen (1994) dikutip dari Shi (2017) mengatakan bahwa strategi belajar bahasa merupakan proses-proses yang secara sadar dipilih oleh pembelajar bahasa untuk meningkatkan kemampuan berbahasanya. Definisi tersebut menunjukkan proses-proses 
yang dapat ditempuh untuk mempelajari sebuah bahasa untuk meningkatkan kemampuan berbahasa seseorang. Pembelajaran bahasa, termasuk di dalamnya pembelajaran Bahasa Inggris dipengaruhi oleh 3 faktor penting, yaitu invidu atau pembelajar, lingkungan, serta faktor konstektual (Nguyen \& Terry, 2017). Kesuksesan sebuah pembelajaran Bahasa Inggris tidak hanya dipengaruhi oleh faktor pembelajar semata, namun juga dipengaruhi oleh faktorr pembelajaran, lingkungan, dan konteks pembelajaran yang sesuai.

Pelaku wisata atau pelaku pariwisata merupakan seluruh pihak yang terlibat dalam kegiatan pariwisata (Meray et al., 2016). Dunia pariwisata melibatkan partisipasi dari banyak pihak, seperti pemerintah, masyarakat, pebisnis, dan lain sebagainya. Damanik dalam Meray, dkk. (2016) menyebutkan enam pihak yang dapat dikategorikan sebagai pelaku wisata dan pelaku pariwisata. Pihak-pihak yang termasuk dalam pelaku wisata atau pelaku pariwisata menurut Damanik adalah (1) wisatawan, (2) penyedia jasa pariwisata, (3) pendukung wisata, (4) masyarakat, (5) pemerintah, dan (6) Lembaga Swadaya Masyarakat (LSM). Dalam penelitian ini, yang dimaksud dengan pelaku wisata atau pariwisata adalah penyedia jasa, pendukung wisata, dan masyarakat di Desa Wisata Tista. Penyedia jasa di Desa Wisata Tista adalah ketua kelompok sadar wisata atau pokdarwis. Selain itu, yang termasuk dalam penyedia jasa wisata adalah pemandu wisata, administrator yang berperan sebagai penyedia informasi. Sedangkan pendukung wisata merupakan penyedia makanan untuk wisatawan. Masyarakat juga termasuk dalam kategori pelaku wisata dalam penelitian ini.

\subsection{Teori}

Penggunaan Bahasa Inggris oleh para pelaku pariwisata tidak terlepas dari berbagai permasalahan. Rani (2016) menyebutkan terdapat 5 hambatan dalam berkomunikasi. 
1. Attitudinal Barrier atau hambatan yang bersumber dari sikap dalam berkomunikasi. Ini berkaitan dengan bagaimana penutur melihat lawan bicaranya sehingga akan mempengaruhi bahasa yang digunakan.

2. Behavioural Barrier yang juga memiliki hubungan dengan sikap kita terhadap lawan bicara kita. Hambatan ini disebabkan oleh adanya stereotip dan generalisasi yang membuat kita melakukan diskriminasi terhadap lawan bicara kita.

3. Cultural Barrier yang merupakan hambatan yang disebabkan oleh adanya perbedaan budaya sehingga timbul suatu kendala dalam berkomunikasi.

4. Language Barrier merupakan hambatan dalam berkomunikasi yang disebabkan oleh adanya perbedaan bahasa serta perbedaan tingkat penguasaan suatu bahasa. Ini terjadi ketika orang yang terlibat dalam komunikasi menggunakan bahasa yang berbeda dan berkomunikasi menggunakan satu bahasa, Bahasa Inggris misalnya, tetapi terdapat perbedaan tingkat penguasaan bahasa.

5. Environmental Barrier atau hambatan yang datang dari lingkungan si penutur dan bisa dikatakan bahwa ini merupakan faktor eksternal yang menghambat terjadi komunikasi yang efektif.

Untuk meminimalisir permasalahan dan kendala dalam berkomunikasi menggunakan Bahasa Inggris, maka keterampilan Bahasa Inggris para pelaku wisata perlu ditingkatkan dengan menggunakan strategi yang tepat. Altan (2004) dikutip dari Weda (n.d.) mengatakan bahwa strategi belajar yang tidak efektif atau kurang efektif akan mengantarkan pada proses belajar yang lambat. Begitu juga sebaliknya, strategi belajar yang tepat dan efektif akan mempermudah dan mempercepat proses pembelajaran Bahasa Inggris. Berdasarkan hal 
tersebut, menerapkan strategi belajar yang tepat dalam proses pembelajaran Bahasa Inggris merupakan hal yang perlu menjadi perhatian guru atau pendidik.

Murcia (2001) dikutip dari Noviyenty (2018) mengungkapkan bahwa strategi belajar merupakan kegiatan, langkah, dan teknik yang spesifik untuk mengatasi kesulitan berbahasa sehingga dapat meningkatkan proses pembelajaran. Kesulitan dalam menggunakan bahasa tertentu, khususnya Bahasa Inggris seharusnya dapat diatasi dengan sebuah pembelajaran Bahasa Inggris yang mengimplementasikan strategi belajar yang tepat. Pemilihan strategi belajar Bahasa Inggris yang baik mendorong pembelajar untuk mengatasi permasalahan dan kendala Bahasa Inggris yang dihadapi oleh pembelajar. Cohen (1994) dikutip dari Shi (2017) mengatakan bahwa strategi belajar bahasa merupakan proses yang secara sadar dipilih oleh pembelajar bahasa untuk meningkatkan kemampuan berbahasanya. Definisi tersebut menunjukkan proses yang dapat ditempuh untuk mempelajari sebuah bahasa untuk meningkatkan kemampuan berbahasa seseorang.

Michae dan Harris (1999) dalam Mandasari \& Oktaviani (2018) mengelompokkan strategi belajar Bahasa Inggris ke dalam enam kelompok besar. Enam kelompok besar tersebut adalah sebagai berikut.

\section{a. Memory Strategy}

Strategi ini membantu pembelajar untuk menguasai Bahasa Inggris dengan mengingat bahasa yang dipelajari. Implementasi strategi ini melibatkan penggunaan gambar, audio, video, dan gerakan tubuh. Gambar, audio, video, dan gerakan tubuh tersebutlah yang akan diingat oleh pembelajar sehingga memiliki pemahaman dan pengetahuan yang lebih baik tentang bahasa yang dipelajari. 


\section{b. Cognitive Strategy}

Strategi ini memungkinkan pembelajar Bahasa Inggris untuk mempelajari Bahasa Inggris melalui kegiatan mencatat, menganalisis, melakukan outline, berlatih dalam situasi yang natural, dan lain-lain.

c. Compensation Strategy

Strategi ini memberikan kesempatan kepada pembelajar Bahasa Inggris untuk menebak arti kata dalam Bahasa Inggris sesuai dengan konteks penggunaannya.

d. Metacognitive Strategy

Strategi ini condong kepada pengelolaan proses pembelajaran secara utuh. Pembelajar Bahasa Inggris diberi kesempatan unyuk merencanakan tugas yang akan dikerjakan, melakukan evaluasi, dan sebagainya.

e. Affective Strategy

Strategi ini memberikan pengaruh besar pada motivasi pembelajar Bahasa Inggris untuk meningkatkan keterampilan berbahasa Inggris. Implementasi strategi dapat dilakukan dengan memberikan pujian atau timbal balik yang positif jika pembelajar menunjukkan peningkatan dalam berbahasa Inggris.

\section{f. Social Strategy}

Strategi terakhir ini memungkinkan pembelajar Bahasa Inggris untuk memahami bahasa dan budaya. Contoh dari strategi ini adalah percakapan dengan penutur asli.

\section{Metode Penelitian}

Penelitian ini didesain atau dirancang sebagai sebuah penelitian deskriptif kualitatif. Suyitno (2010) menyebutkan bahwa metode deskriptif merupakan suatu metode penelitian yang digunakan untuk mencari dan menemukan unsur-unsur, ciri-ciri, dan sifat-sifat suatu 
fenomena. Metode ini terdiri dari tiga langkah, yaitu mengumpulkan data, menganalisis data, dan mengintepretasikan data. Tiga langkah tersebut itulah yang akan dilakukan dalam penelitian ini. Data akan dikumpulkan melalui instrument penelitian yang akan dikembangkan serta akan melibatkan informan-informan terkait. Setelah data terkumpul, data akan dianalisis untuk menemukan kendala dan tantangan yang dihadapi oleh pelaku wisata di Desa Wisata Tista dalam berkomunikasi menggunakan Bahasa Inggris. Selanjutnya hasil analisis akan diintepretasikan dengan sistematis dan objektif sehingga akan ditemukan strategi yang tepat untuk meningkatkan kemampuan Bahasa Inggris para pelaku wisata di Desa Wisata Tista Tabanan.

Penelitian ini menggunakan data kualitatif. Data kualitatif berupa gambaran umum Desa Wisata Tista, aktifitas wisata di Desa Wisata Tista, serta hasil wawancara dengan pengelola Desa Wisata Tista, baik itu yang berhubungan dengan penggunaan Bahasa Inggris serta permasalahan dan kendala yang dihadapi. Data-data tersebut diperoleh dari dua jenis sumber data, yaitu sumber data primer dan sumber data sekunder. Sumber data primer secara sederhana dapat dikatakan sebagai sumber data pertama atau sumber data langsung. Sedangkan sumber data sekunder adalah sumber data tak langsung. Sumber data primer dalam penelitian ini merupakan kejadian langsung di lapangan, pengelola desa wisata, serta pelaku wisata, seperti pemandu wisata, pengelola homestay. Untuk melengkapi data primer, digunakan juga data yang diperoleh dari sumber data sekunder, seperti literatur, buku, dan artikel ilmiah. Dalam penelitian ini data langsung atau primer diperoleh dengan melaksanakan observasi langsung, wawancara, kepada kelompok Pokdarwis Desa Wisata Tista. 


\section{Hasil dan Pembahasan}

Seperti yang ditemukan pada penelitian sebelumnya bahwa masyarakat khususnya pelaku wisata di Desa Wisata Tista masih mengalami kendala untuk berkomunikasi dengan wisatawan, khususnya wisatawan asing. Hal ini dikarenakan keterbatasan keterampilan Bahasa Inggris yang dimiliki oleh masyarakat maupun pelaku wisata di Desa Wisata Tista sehingga akan mempengaruhi kualitas komunikasi yang terjadi antara pelaku wisata dengan wisatawan. Tidak menutup kemungkina jika kendala dalam berkomunikasi ini terus terjadi, maka akan menurunkan tingkat kepuasan wisatawan terhadap pelayanan yang diberikan sehingga turut pula berkontribusi dalam penurunan jumlah wisatawan yang berkunjung.

Permasalahan pertama yang diangkat dalam penelitian ini menyangkut kendala dan tantangan yang dihadapi oleh masyarakat maupun pelaku wisata dalam berbasaha Inggris. Kendala serta tantangan yang dihadapi sangat penting untuk dijabarkan secara rinci untuk menentukan strategi atau langkah yang dapat diambil untuk meminimalkan resiko yang dapat ditimbulkan. Untuk mengetahui kendala yang dihadapi, wawancara dilakukan dengan Kepala Kelompok Sadar Wisata Desa Wisata Tista, serta melakukan wawancara dengan beberapa masyarakat serta pelaku wisata. Berikut adalah kendala dan tantangan yang dihadapi oleh masyarakat dan pelaku wisata di Desa Wisata Tista.

a. Masyarakat yang memiliki kemampuan berbahasa Inggris sangatlah terbatas

Menurut hasil wawancara yang dilakukan pada Bulan Agustus 2020 dengan Kepala Pokdarwis Desa Wisata Tista, jumlah masyarakat yang memiliki keterampilan berbahasa Inggris masih sangat terbatas jumlahnya. Keterbatasan keterampilan Bahasa Inggris ini menyebabkan tidak semua masyarakat dapat berperan aktif dalam 
kegiatan wisata di Desa Wisata Tista, khususnya kegiatan wisata yang berhubungan dengan wisatawan asing. Untuk mengatasi permasalahan tersebut, pihak Pokdarwis Desa Wisata Tista tetap memaksimalkan masyarakatnya yang tinggal di Kota Denpasar atau Kabupaten Badung. Ketika menerima kunjungan wisatawan asing, pihak Pokdarwis Desa Wisata Tista akan meminta masyarakatnya yang mampu berbahasa Inggris, meskipun masyarakat tersebut menetap di Kota Denpasar dan Kabupaten Badung untuk "pulang" dan membantu menjadi pemandu wisata.

b. Keterbatasan dalam keterampilan berbicara dengan Bahasa Inggris

Kendala lain yang dihadapi oleh masyarakat khususnya para pelaku wisata di Desa Wisata Tista adalah keterbatasan keterampilan berbicara dalam Bahasa Inggris. Seluruh responden yang diwawancarai mengatakan memiliki kesulitan dalam berbicara menggunakan Bahasa Inggris. Pada dasarnya seluruh responden mengerti apa yang diucapkan oleh wisatawan asing ketika berkomunikasi dengan Bahasa Inggris. Responden dapat menagkap pesan yang disampaikan oleh wisatawan asing. Masyarakat ini bahkan mampu untuk menerjemahkan beberapa teks sederhana. Namun responded memiliki kendala dalam menyampaikan maksud dan pesan kepada wisatawan asing dengan menggunakan Bahasa Inggris. Hasil wawancara pada Bulan Agustus 2020 menyebutkan bahwa keterbatasan ini disebabkan oleh dua faktor utama, yaitu perasaan tidak percaya diri serta kurangnya perbendaharaan kata dalam Bahasa Inggris. Kurangnya perbendaharaan kosa kata dalam Bahasa Inggris menjadi kontirbutor penting dalam keterbatasan dalam keterampilan berbicara dengan Bahasa Inggris. Poin ini akan dibahas pada Poin C. Selain kurangnya kosa kata Bahasa Inggris yang dimiliki, masyarakat dan pelaku wisata ini juga merasa tidak percaya diri jika dihadapkan 
dengan wisatawan asing serta harus berkomunikasi dalam Bahasa Inggris.

c. Keterbatasan dalam penguasaan kosa kata Bahasa Inggris

Kendala ketiga yang dihadapi adalah keterbatasan dalam penguasaan kosa kata dalam Bahasa Inggris. Seluruh responden setuju bahwa perbendaharaan kata Bahasa Inggris menjadi pengahalang dalam berbicara menggunakan Bahasa Inggris dengan wisatawan asing. Responden menyadari bahwa kurangnya perbendaharaan kosa kata Bahasa Inggris yang dimiliki menyebabkan kendala dalam berkomunikasi dengan Bahasa Inggris, khususnya dalam komunikasi secara verbal. Keterbatasan dalam pengusaaan kosa kata dalam Bahasa Inggris merupakan faktor utama yang menjadi penghalang bagi seseorang untuk memiliki keterampilan berbicara dengan Bahasa Inggris yang baik (Khan, Radzuan, Shahbaz, Ibrahim, \& Mustafa, 2018). Salah seorang responden menyatakan bahwa kurang perbendaharaan kosa kata Bahasa Inggris yang dimilikinya adalah akibat dari ketidakmampuannya dalam mengingat dan menghafal banyak kata Bahasa Inggris.

d. Kurang percaya diri dalam berkomunikasi dengan Bahasa Inggris

Permasalahan terkahir yang dihadapi oleh masyarakat dan pelaku wisata di Desa Wisata Tista dalam berkomunikasi dengan Bahasa Inggris adalah kepercayaan diri. Berdasarkan hasil wawancara pada Bulan Agustus 2020 dengan Kepala Pokdarwis Desa Wisata Tista, tidak percaya merupakan salah satu permasalahan yang dialami oleh masyarakat dalam berkomunikasi dengan Bahasa Inggris. Dalam berkomunikasi dengan bahasa asing, khususnya Bahasa Inggris, kepercayaan diri menjadi suatu komponen penting. Kepercayaan diri yang tinggi dapat menuntun seseorang untuk berani berbicara dengan orang asing atau wisatawan asing yang ditemuinya dengan 
menggunakan Bahasa Inggris. Secara tidak langsung dapat dikatakan bahwa percaya diri memiliki korelasi dengan kemampuan Bahasa Inggris, khususnya keterampilan berbicara.

Hal ini sesuai dengan penelitian yang dilaksanakan di Universitas Swadaya Gunung Jati yang menemukan bahwa terdapat korelasi yang signifikan antara tingkat kepercayaan diri mahasiswa untuk berkomunikasi dengan Bahasa Inggris dengan keterampilan berbicara (speaking skill) yang dimiliki (Roysmanto, 2018). Penelitian yang dilaksanakan di IAIN Palangka Raya juga menemukan hal serupa bahwa kepercayaan diri memiliki korelasi dan hubungan yang positif dengan kemampuan berbicara Bahasa Inggris (Fitri, 2015). Semakin tinggi tingkat kepercayaan diri yang dimiliki oleh mahasiswa, maka akan meningkatkan keterampilan berbicara.

Guna meningkatkan keterampilan Bahasa Inggris pelaku wisata di Desa Wisata Tista, maka pemilihan strategi belajar yang tepat perlu menjadi perhatian. Dalam memilih strategi yang tepat, terdapat beberapa hal atau faktor yang dipertimbangkan. Faktor- faktor tersebut adalah kelemahan dan kelebihan yang dimiliki oleh atau ada di Desa Wisata Tista. Berdasarkan hasil observasi dan wawancara yang dilakukan, maka kelebihan dan kekurangan pelaku wisata di Desa Wisata Tista dapat dijabarkan sebagai berikut.

Kelebihan yang yang akan menguntungkan bagi pelaku wisata di Desa Wisata Tista dalam belajar Bahasa Inggris adalah sebagai berikut.

a. Mendapat dukungan dari pengelola Desa Wisata Tista, yaitu Kelompok Sadar Wisata serta mendapat dukungan dari Kepala Desa Tista.

b. Memiliki sumber belajar yang baik berupa wisatawan manca negara yang berkunjug ke Desa Wisata Tista. Wisatawan manca negara ini 
dapat menjadi sumber belajar Bahasa Inggris bagi pelaku wisata di Desa Wisata Tista.

c. Memiliki sumber belajar lain berupa teman-teman sejawat yang mampu berbahasa Inggris. Rekan-rekan sejawat ini merupakan guru yang dapat membantu pelaku wisata yang belum menguasasi Bahasa Inggris.

d. Memiliki akses sumber belajar yang baik berupa internet. Internet menyajikan beragam sumber belajar Bahasa Inggris bagi pelaku wisata di Desa Wisata Tista. Sumber belajar di internet dapat berupa video, film, berita, teks, dan lain sebagainya.

Sedangkan kekurangan yang nantinya dapat menghambar proses belajar Bahasa Inggris para pelaku wisata di Desa Wisata Tista adalah sebagai berikut.

a. Karakteristik pelaku wisata di Desa Wisata Tista yang tergolong pembelajar dewasa sehingga banya yang mengatakan bahwa pelaku wisata tidak mampu mengingat banyak kata.

b. Pelaku wisata di Desa Wisata Tista yang bukan merupakan pembelajar penuh waktu. Bukan pembelajar penuh waktu memiliki arti para pembelajar tidak menggunakan seluruh waktunya untuk belajar. Ini mengingat para pelaku wisata tersebut merupakan pekerja dalam bidang pariwisata atau bidang lain sehingga waktu mereka dialokasikan untuk pekerjaan, keluarga, dan urusan adat.

Berdasarkan kelebihan dan kekurangan tersebut, maka strategi yang dapat diterapkan adalah sebagi berikut. Strategi belajar Bahasa Inggris yang dikemukakan oleh MIchae dan Harris (1999).

a. Memory Strategy

Memory strategy merupakan strategi yang melibatkan penggunaan gambar, video, dan audio dalam belajar. Berikut merupakan contoh implementasi memory strategy untuk membantu 
meningkatkan keterampilan Bahasa Inggris para pelaku wisata di Desa Wisata Tista. Strategi pertama yang dapat diaplikasikan adalah mendengarkan lagu berbahasa Inggris. Masyarakat dan pelaku wisata di Desa Wisata Tista dapat mulai mendengarkan lagu-lagu berbahasa Inggris untuk menambah kosa kata Bahasa Inggris yang dimilikinya. Mendengarkan lagu berbahasa Inggris merupakan suatu kegiatan yang menyenangkan.

Selain mendengarkan lagu berbahasa Inggris, menonton film berbahasa Inggris juga merupakan salah satu strategi untuk meningkatkan penguasaan kosa kata Bahasa Inggris. Selain film, video berbahasa Inggris juga merupakan sumber belajar kosa kata yang mudah untuk diakses. Masyarakat dan pelaku wisata di Desa Wisata Tista memiliki akses yang mudah pada situs penyedia film atau video, seperti YouTube. YouTube dapat dimanfaatkan untuk menambah kosa kata Bahasa Inggris guna meningkatkan keterampilan Bahasa Inggris secara umum. Disarankan bagi masyarakat dan pelaku wisata di Desa Wisata Tista untuk mengakses video singkat berbahasa Inggris sehingga dapat menemukan kosa kata baru serta dapat belajar bagaimana melafalkan kata-kata tersebut serta bagaimana menggunakannya dalam konteks sehari-hari.

\section{b. Cognitive Strategy}

Strategi kedua yang dapat diimplementasikan adalah cognitive strategy dimana akan melibatkan proses latihan dalam situasi yang natural serta proses mencatat hal-hal penting dalam belajar. Berikut contoh implementasi cognitive strategy dalam konteks di Desa Wisata Tista. Setelah mendengarkan lagu berbahasa Inggris dan menonton film atau video berbahasa Inggris, masyarakat dan pelaku wisata di Desa Wisata Tista dapat menerapkan strategi Vocabulary Notebook. Vocabulary Notebook merupakan suatu strategi dimana masyarakat 
perlu menyiapkan sebuah buku tulis yang akan digunakan untuk mencatat seluruh kosa kata Bahasa Inggris yang diperoleh dari lagu, film, dan video yang ditonton. Ini membantu masyarakat untuk mengingat lebih banyak kosa kata Bahasa Inggris. Selain itu, strategi yang dapat diimplementasikan dan diaplikasikan untuk meningkatkan keterampilan berbicara dalam Bahasa Inggris adalah memperbanyak latihan percakapan Bahasa Inggris. Bagi masyarakat dan pelaku wisata di Desa Wisata Tista percakapan dapat dilakukan dengan rekan kerja yang memiliki keterampilan Bahasa Inggris yang baik. Strategi ini telah banyak diteliti untuk mengetahui efektifitasnya dalam meningkatkan keterampilan bicara. Sesuai dengan keadaan saat ini di Desa Wisata Tista, beberapa masyarakat yang bekerja di sektor pariwisata di Kota Denpasar dan Kabupaten dapat menjadi sumber belajar Bahasa Inggris yang baik. Masyarakat Desa Wisata Tista yang saat ini tidak memiliki keterampilan berbicara Bahasa Inggris yang belum mumpuni dapat belajar dengan melakukan percakapan Bahasa Inggris sederhana dengan rekan yang mampu berbahasa Inggris dengan baik.

Namun keterampilan bebrbahasa Inggris berkaitan erat dengan kepercayaan diri pembelajar. Kepercayaan diri merupakan sesuatu yang personal yang dimiliki oleh setiap orang. Kepercayaan diri sangat bergantung pada dukungan yang diperoleh dari lingkungan sekitar serta motivasi yang berasal dari dalam diri. Talk to Everyone merupakan implementasi dari cognitive strategy untuk menumbuhkan kepercayaan diri mengingat ketika berbicara atau hanya menyapa orang ditemui dapat menumbuhkan rasa familiar untuk berbicara. Jika kegiatan ini dilakukan secara terus menerus, maka masyarakat akan merasa terbiasa untuk berbicara dengan banyak orang. 
Strategi lain yang dapat dilakukan untuk meningkatkan kepercayaan diri untuk berkomunikasi dengan menggunakan Bahasa Inggris adalah dengan melakukan role play. Kegiatan role play merupakan aktifitas yang lumrah dan sering digunakan dalam pembelajaran Bahasa Inggris. Role play dapat melatih keterampilan berbicara dalam Bahasa Inggris. Selain itu, role play juga mampu menumbuhkan kepercayaan diri pembelajar Bahasa Inggris. Dengan melakukan role play, pembelajar dapat mengesampingkan rasa malu yang dimiliki sehingga dapat menjadi terbiasa dan nyaman dalam berkomunikasi dengan Bahasa Inggris.

c. Affective Strategy

Affective strategy dalam belajar Bahasa Inggris dapat diimplementasikan dalam bentuk apresiasi atau penghargaan terhadap kerja keras dalam belajar Bahasa Inggris. Dalam konteks di Desa Wisata Tista, pengelola Pokdarwis dapat membentuk sebuah klub Bahasa Inggris. Klub tersebut merupakan pusat belajar Bahasa Inggris di Desa Wisata Tista. Pengelola dapat bekerja sama dengan perguruan tinggi di Bali yang telah menjalin kerja sama dengan Desa Wisata Tista untuk membantu memfasilitasinya. Dalam proses belajar di klub tersebut, pengelola dapat memberikan apresiasi serta motivasi bagi pelaku wisata untuk meningkatkan keterampilan Bahasa Inggris.

\section{d. Social Strategy}

Strategi terakhir yang dapat dilakukan adalah social strategy yang melibatkan penutur asli Bahasa Inggris untuk meningkatkan keterampilan Bahasa Inggris. Pelaku wisata di Desa Wisata Tista dapat memperbanyak percakapan Bahasa Inggris dengan wisatawan asing yang datang berkunjung ke Desa Wisata Tista. Ketika terdapat wisatawan asing yang datang berkunjung, masyarakat dapat mengajak wisatawan berbincang sederhana dengan menggunakan Bahasa 
Inggris yang sederhana. Sebagai salah satu destinasi pariwisata yang besar, Bali merupakan tempat belajar Bahasa Inggris yang baik mengingat banyaknya orang asing yang datang berkunjung. Masyarakat dan pelaku wisata di Desa Wisata Tista dapat berkunjung ke daerah wisata, seperti Tanah Lot, Canggu, Kuta, Seminyak, atau Nusa Dua untuk bertemu dengan wisatawan asing serta melakukan percakapan sederhana.

\section{Simpulan dan Rekomendasi}

Hasil wawancara dan observasi yang dilakukan di Desa Wisata Tista dapat ditarik kesimpulan bahwa Desa Wisata Tista merupakan salah satu desa wisata di Bali yang memiliki beragam potensi wisata yang menarik untuk dikunjungi oleh wisatawan baik itu wisatawan domestik maupun wisatawan manca negara. Selain itu, desa wisata ini dapat dikatakan telah memiliki sistem manajemen yang baik melihat dari proses administrasi yang baik serta telah terbentuknya kelompok sadar wisata yang bertanggung jawab terhadap aktifitas wisata di desa tersebut. keterlibatan masyarakat serta dukungan penting diberikan untuk kemajuan Desa Wisata Tista.

Namun tidak dapat dielakkan bahwa sumber daya manusia atau SDM di Desa Wisata Tista masih memiliki keterbatasan, khususnya keterbatasan dalam berbahasa Inggris. Masyarakat dan pelaku wisata di Desa Wisata Tista masih terbatas jumlah. Komunikasi dengan wisatawan asing masih mengandalkan peran pelaku wisata dan masyarakat yang tidak banyak jumlahnya. Selain itu, keterampilan berbicara dalam Bahasa Inggris masih dikategorikan kurang. Ini disebabkan oleh kurangnya kosa kata Bahasa Inggris yang dimiliki oleh masyarakat dan pelaku wisata. Selain itu, masyarakat dan pelaku wisata tidak memiliki kepercayaan diri yang tinggi untuk berkomunikasi dalam Bahasa Inggris. 
Kendala-kendala tersebut dapat diatasi atau diminimalisir dengan mengaplikasikan atau mengimplementasikan beberapa strategi seperti memperbanyak percakapan dalam Bahasa Inggris untuk meningkatkan kemampuan berbicara. Untuk memperkaya kosa kata, dapat dilakukan dengan mendengarkan lagu berbahasa Inggris, menonton film dan video berbahasa Inggris serta dengan membuat catatan kata-kata Bahasa Inggris yang dipelajari.

Berdasarkan hasil wawancara dan observasi, beberapa saran dapat diberikan kepada pihak-pihak terkait.

a. Pengelola Kelompok Sadar Wisata di Desa Wisata Tista sudah saatnya untuk memberi perhatian lebih kepada kualitas SDM mengingat kualitas SDM sangat mempengaruhi kualitas layanan yang diberikan kepada wisatawan. Perhatian terhadap kualitas pelayanan dapat dilakukan dengan menyelenggarakan pelatihan, khususnya pelatihan Bahasa Inggris dengan mengundang guru-guru atau dosen Bahasa Inggris.

b. Peneliti selanjutnya dapat melakukan penelitian lebih mendalam tentang tingkat keterampilan Bahasa Inggris yang dimiliki oleh masyarakat dan pelaku wisata di Desa Wisata Bongan agar mampu melihat aspek yang perlu ditingkatkan.

c. Dosen Bahasa Inggris dapat menjadikan Desa Wisata Tista sebagai tempat untuk melaksanakan kegiatan Pengabdian kepada Masyarakat (PkM) berupa pelatihan Bahasa Inggris bagi pelaku wisata di Desa Wisata Tista.

\section{Daftar Pustaka}

Husain, N. (2015). What is Language? English Language Language as Skill. Language and Language Skills, March, 1-11. https://www.researchgate.net/publication/274310952

Mandasari, B., \& Oktaviani, L. (2018). English Language Learning Strategies: an Exploratory Study of Management and Engineering 
Students. Premise: Journal of English Education, 7(2), 61. https://doi.org/10.24127/pj.v7i2.1581

Meray, J. G., Tilaar, S., \& Takumansang, E. D. (2016). Partisipasi Masyarakat Terhadap Pengembangan Pariwisata Pantai Mahembang Kecamatan Kakas. Spasial, 3(3), 47-55.

Nguyen, H., \& Terry, D. R. (2017). English Learning Strategies among EFL Learners: A Narrative Approach. IAFOR Journal of Language Learning, 3(1), 4-19. https://doi.org/10.22492/ijll.3.1.01

Noviyenty, L. (2018). Strategies in Learning and Techniques in Teaching English Speaking. ENGLISH FRANCA: Academic Journal of English Language and Education, 2(1), 35. https://doi.org/10.29240/ef.v2i1.454

Sadiku, L. M. (2015). The Importance of Four Skills Reading, Speaking, Writing, Listening in a Lesson Hour. European Journal of Language and Literature, 1(1), 29. https://doi.org/10.26417/ejls.v1i1.p29-31

Weda, S. (n.d.). ENGLISH LANGUAGE LEARNING STRATEGIES: ATTEND TO FROM AND ATTEND TO MEANING STRATEGIES (A CASE STUDY AT SMA NEGERI 9 MAKASSAR). 110(9), 1689-1699.

\section{Profil Penulis}

Luh Sri Damayanti merupakan dosen Bahasa Inggris di Prodi Diploma 4 Manajemen Perhotelan, Politeknik Internasional Bali. Penulis memiliki latar belakang di pendidikan Bahasa Inggris. Penulis menamatkan strata 1 di Program Studi Pendidikan Bahasa Inggris dan kemudian melanjutkan ke jenjang magister di universitas yang sama dan mengambil jurusan yang sama. Penulis memiliki ketertarikan pada topik-topik penelitian seputar pendidikan, pendidikan Bahasa Inggris, linguistik, dan Bahasa Inggris dalam dunia pariwisata. 